\title{
Wpływ temperatury austenizowania na mikrostrukturę i twardość stali typu Hardox $\mathbf{4 5 0}$
}

\author{
Effect of austenitizing temperature on the microstructure \\ and hardness of Hardox 450 steel
}

\section{Streszczenie}

W pracy przedstawiono symulację wpływu temperatury na zakres przemian fazowych w strefie wpływu ciepła w obszarze temperatur przegrzania. Wybrano pięć różnych temperatur austenityzowania, tj.: 900, 1000, 1100, 1200 oraz $1300^{\circ} \mathrm{C}$. Symulacje nagrzewania i chłodzenia wykonano na wysokorozdzielczym dylatometrze L78 R.I.T.A. Po austenityzowaniu, próbki chłodzono z dwoma wybranymi szybkościami 5 i $1^{\circ} \mathrm{C} / \mathrm{s}$ do temperatury pokojowej. Na próbkach po ochłodzeniu wykonano analizę mikrostruktury i twardości. W oparciu o przedstawione wyniki określono wpływ temperatury na hartowność w zakresie badanych szybkości chodzenia i w konsekwencji zmian w mikrostrukturze oraz jednorodności uzyskanych map twardości.

Słowa kluczowe: cykl cieplny; austenityzacja; obróbka cieplna

\begin{abstract}
The paper presents the simulation of the temperature effect on phase transformation in the heat-affected zone in the area of superheat temperatures. Five different temperatures were selected, i.e. $900,1000,1100,1200$ and $1300{ }^{\circ} \mathrm{C}$. Heating and cooling simulations were carried out on the L78 R.I.T.A high-resolution dilatometer. After austenitizing, the samples were cooled with two selected rates 5 and $1{ }^{\circ} \mathrm{C} / \mathrm{s}$. On the samples after cooling, microstructure analysis and hardness distribution analysis were performed. Based on the results, the influence of temperature on the increase of hardenability in the range of the tested cooling rates was determined and as a consequence changes in the microstructure and homogeneity of the obtained hardness maps.
\end{abstract}

Keywords: thermal cycle; austenitization; heat treatment

\begin{abstract}
Wstęp
Stale typu Hardox charakteryzują się drobnoziarnistością, wysoką wytrzymałością, odpornością na pękanie w warunkach dynamicznych i odpornością na ścieranie. Skład chemiczny tych stali opracowano w Szwecji pod koniec lat 70. ubiegłego stulecia. Oprócz węgla w ilości od $0,15 \%$ do nawet $0,45 \%$, manganu ok. $1,6 \%$, krzemu ok. $0,7 \%$ i innych pierwiastków takich jak chrom, nikiel i molibden, zawierają bor w ilości 0,002 $\div 0,004 \%$. Taka kombinacja składu chemicznego oraz dobór odpowiednich parametrów obróbki cieplnej; przede wszystkim temperatury austenityzowania pozwala na uzyskanie oprócz wspomnianych wyżej własności, także dobrej hartowności. Stale Hardox są produkowane przez szwedzki koncern SSAB-Oxelösund [1]. Obecnie jest wytwarzane 6 gatunków tej stali. Stale te są określane przez producenta jako „wysokojakościowe stale odporne na ścieranie". Są one spawalne, a ich obróbka skrawaniem jest możliwa tylko przy pomocy specjalistycznych urządzeń. Podział stali Hardox opiera się na podstawie ich twardości mierzonej w skali Brinella $[1,2]$.
\end{abstract}

Wspomniane wyżej własności stali Hardox osiągane są poprzez precyzyjnie dobrany skład chemiczny oraz małą zawartość szkodliwych domieszek pierwiastków, tj. fosforu i siarki. W zależności od grubości produkowanej blachy, stale te mają różne zawartości węgla oraz dodatków stopowych. Ilości tych pierwiastków są dobierane w taki sposób, aby w jak największym stopniu kontrolować twardość danego gatunku stali oraz wyrobu z niej uzyskanego [2:5].

Geneza bainitycznych lub martenzytycznych spawalnych stali o wysokiej wytrzymałości wywodzi się ze zmiany metody podwyższania wytrzymałości stopów Fe-C. W rezultacie tych prac uzyskano grupę stali bainitycznych spawalnych $z$ dodatkiem boru o wytrzymałości na rozciąganie w przedziale $530 \div 1200 \mathrm{MPa}$. Martenzytyczne stale z grupy Hardox wykazują wytrzymałość na rozciąganie od $1250 \mathrm{MPa}$ (Hardox 400) do $2000 \mathrm{MPa}$ (Hardox 600) [1 $\div 9]$.

Dużą rolę w stalach Hardox odgrywa dodatek boru, który już w bardzo małych ilościach wpływa na hartowność, zwiększając ją w znacznym stopniu. Wpływ ten rośnie wraz

Dr inż. Rafał Dziurka - AGH Akademia Górniczo-Hutnicza; dr inż. Beata Łętkowska - Politechnika Wrocławska, mgr inż. Wiktoria Zbyrad-Kołodziej - Politechnika Rzeszowska

Autor korespondencyjny/Corresponding author. dziurka@agh.edu.pl 
z rozdrobnieniem ziarna w stali. Drugim czynnikiem zwiększającym wpływ boru na hartowność jest obniżenie zawartości węgla. Dodatek boru oraz niobu i tytanu wpływa na zmniejszenie współczynnika CEV, zarazem podnosząc własności mechaniczne $[2 \div 4,10,11]$.

Analizę przemian zachodzących w SWC połączenia spawanego prowadzi się najczęściej na podstawie wykresów przemiany przechłodzonego austenitu w warunkach spawalniczych cykli cieplnych (CTPc-S). W związku z tym, że istotny wpływ na przebieg przemian fazowych, a szczególnie na czas ich rozpoczęcia i zakończenia ma temperatura i czas austenityzacji, wykres CTPc-S wyznaczony dla jednej temperatury maksymalnej cyklu cieplnego spawania nie pozwala na przeprowadzenie analizy zmian strukturalnych w całym obszarze SWC. Wykres taki pozwala jedynie analizować obszar SWC, w którym wystąpiły zbliżone temperatury maksymalne cyklu cieplnego spawania. Dopiero wykonanie serii wykresów CTPc-S, różniących temperaturami cyklu cieplnego pozwala na dokładną analizę przemian w całym zakresie SWC $[10,12,13]$. Niniejsza praca stanowi uzupełnienie baz danych, w zakresie wpływu temperatury austenityzowania w sferze $900 \div 1300{ }^{\circ} \mathrm{C}$ na przemiany fazowe przechłodzonego austenitu w wybranym gatunku, Hardox 450 .

\section{Materiał do badań}

W badaniach użyto szeroko stosowaną stal w gatunku Hardox 450. Stal tę dostarczono w postaci pręta o wymiarach $\varnothing 300$ x 100 mm przez firmę SSAB Poland sp. z o.o., po ulepszaniu cieplnym. Skład chemiczny wg danych wytopowych dostawcy podano $\mathrm{w}$ tablicy I, a na rysunku 1 przedstawiono jej mikrostrukturę.

Analizując skład chemiczny badanej stali zwraca uwagę zawartość boru na poziomie 0,0011\%. Dodatkowo w składzie chemicznym stali można wyróżnić niewielkie dodatki $\mathrm{V}$, Ti i Nb, które w takich ilościach będą ograniczać rozrost ziarna austenitu. Mikrostruktura stali Hardox 450 w stanie dostawy składała się z odpuszczonego martenzytu.

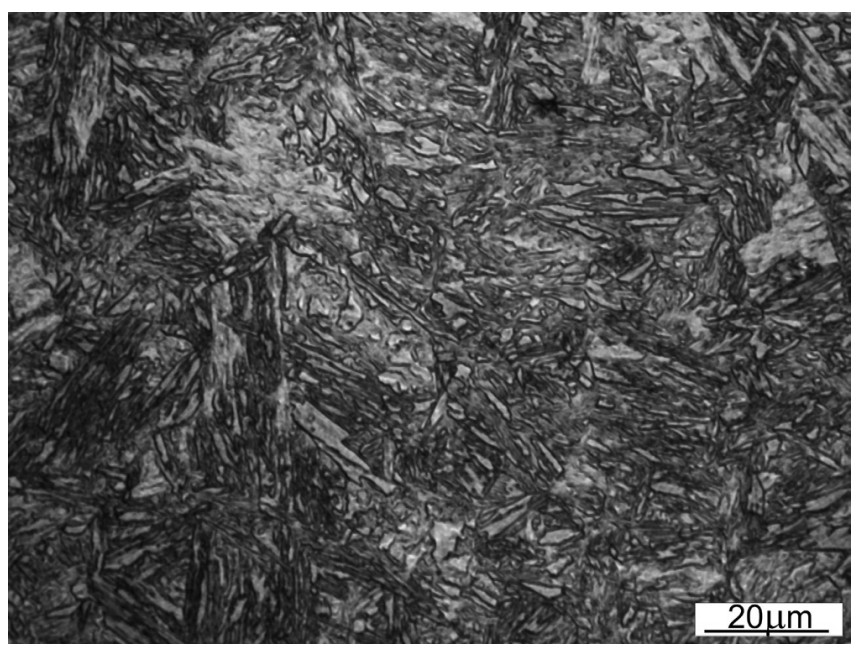

Rys. 1. Mikrostruktura badanej stali Hardox w stanie dostawy, traw. $2 \%$ nital

Fig. 1. Microstructure of the Hardox steel in the delivery condition, etched with $2 \%$ nital

Tablica I. Skład chemiczny badanej stali Hardox 450 (\% masowy) Table I. Chemical composition of the Hardox 450 steel (mass\%)

\section{Metodyka i wyniki badań}

W pracy postanowiono zasymulować wpływ temperatur na przemiany fazowe w strefie wpływu ciepła w obszarze temperatur przegrzania. Wybrano pięć różnych temperatur austenityzowania, tj.: 900, 1000, 1100, 1200 oraz $1300{ }^{\circ} \mathrm{C}$. Badania nagrzewania i chłodzenia wykonano na wysokorozdzielczym dylatometrze L78 R.I.T.A. firmy Linseis. Próbki stali Hardox 450 wymiarach $\emptyset 3 \mathrm{~mm}, \mathrm{~h}=10 \mathrm{~mm}$ nagrzewano indukcyjnymi prądami wirowymi z szybkością $5^{\circ} \mathrm{C} / \mathrm{s}$ do wybranych temperatur austenityzowania. Atmosferę stanowił gaz obojętny argon pod ciśnieniem 2 bar. Po austenityzowaniu, próbki chłodzono z dwoma wybranymi szybkościami 5 i $1{ }^{\circ} \mathrm{C} / \mathrm{s}$ do temperatury pokojowej. Wykonano tzw. zgłady metalograficzne, zmierzono ich twardość i wykonano fotografie ich mikrostruktury. Badania metalograficzne wykonano przy użyciu mikroskopu świetlnego Axiovert 200 MAT firmy ZEISS. Zgłady trawiono nitalem o składzie: $2 \% \mathrm{HNO}_{3}$ $+98 \% \mathrm{C}_{2} \mathrm{H}_{5} \mathrm{OH}$. Pomiary twardości wykonano przy użyciu twardościomierza Wilson Hardness TUKON 2500 stosując metodę Vikersa przy obciążeniu 2,94 N. Dodatkowo, na próbkach po chłodzeniu dokonano analizy rozkładu twardości. Wykonano po 36 pomiarów twardości, tworząc kwadrat pomiarowy liczący 6 x 6 odcisków w odstępie 0,3 mm, dzięki czemu wykonano mapę rozkładu twardości.

Na rysunku 2 przedstawiono dylatogramy chłodzenia próbek uprzednio nagrzanych do wybranych wartości temperatury austenityzowania, a następnie chłodzonych z tą samą szybkością wynoszącą $1{ }^{\circ} \mathrm{C} / \mathrm{s}$. Natomiast na rysunku 3 podobny zestaw krzywych dla szybkości chłodzenia $5{ }^{\circ} \mathrm{C} / \mathrm{s}$.

Dla próbki chłodzonej z szybkością $1{ }^{\circ} \mathrm{C} / \mathrm{s}$ od temperatury $900{ }^{\circ} \mathrm{C}$ występują efekty dylatacyjne świadczące o obecności w mikrostrukturze próbki, zarówno ferrytu, perlitu, jak i bainitu. Podwyższenie temperatury austenityzowania wpłynęło na zmniejszenie efektu dylatacyjnego pochodzącego od przemian dyfuzyjnych w szczególności perlitu. Przy temperaturze austenityzowania $1100{ }^{\circ} \mathrm{C}$ obserwuje się zanik efektu od przemiany perlitycznej, a dominują jedynie efekty dylatacyjne związane z powstawaniem ferrytu i bainitu. Widoczny coraz bardziej efekt od przemiany bainitycznej, jednoznacznie świadczy o zwiększeniu hartowności badanej stali, związanej z rozrostem ziarna.

W przypadku krzywych dylatacyjnych chłodzenia z szybkością $5^{\circ} \mathrm{C} / \mathrm{s}$ (rys. 3) można zauważyć, że zwiększenie szybkości chłodzenia spowodowało zanik efektów dylatacyjnych, pochodzących od przemian dyfuzyjnych. Jednocześnie obserwuje się wyraźny dominujący efekt dylatacyjny związany z powstawaniem bainitu. Dodatkowo, na krzywych chłodzenia dla szybkości $5{ }^{\circ} \mathrm{C} / \mathrm{s}$ przy każdej temperaturze austenityzowania obserwuje się dodatkowy efekt dylatacyjny od przemiany martenzytycznej.

$\mathrm{Na}$ rysunku 4 i 5 zamieszczono fotografie mikrostruktury próbek chłodzonych z temperatur austenityzowania $900 \div 1300{ }^{\circ} \mathrm{C}$ odpowiednio z szybkością 1 i $5{ }^{\circ} \mathrm{C} / \mathrm{s}$ oraz odpowiadające im mapy twardości.

W mikrostrukturze próbki dylatometrycznej po chłodzeniu z szybkością $1{ }^{\circ} \mathrm{C} / \mathrm{s}$ od temperatury $900{ }^{\circ} \mathrm{C}$ uzyskano ferryt, perlit i niewielkie ilości bainitu. Po zwiększeniu temperatury austenityzowania do $1000^{\circ} \mathrm{C}$ następuje znaczny wzrost udziału objętościowego bainitu, przy czym w mikrostrukturze nadal zauważalne są obszary ferrytyczno-perlityczne.

\begin{tabular}{|c|c|c|c|c|c|c|c|c|c|c|c|c|c|}
\hline $\mathbf{C}$ & $\mathbf{M n}$ & $\mathbf{S i}$ & $\mathbf{P}$ & $\mathbf{S}$ & $\mathbf{C r}$ & $\mathbf{N i}$ & $\mathbf{M o}$ & $\mathbf{C u}$ & $\mathbf{V}$ & $\mathbf{T i}$ & $\mathbf{N b}$ & $\mathbf{B}$ & $\mathbf{F e}$ \\
\hline 0,22 & 1,32 & 0,49 & 0,009 & 0,004 & 0,78 & 0,04 & 0,012 & 0,015 & 0,004 & 0,020 & 0,005 & 0,0011 & reszta \\
\hline
\end{tabular}


a)

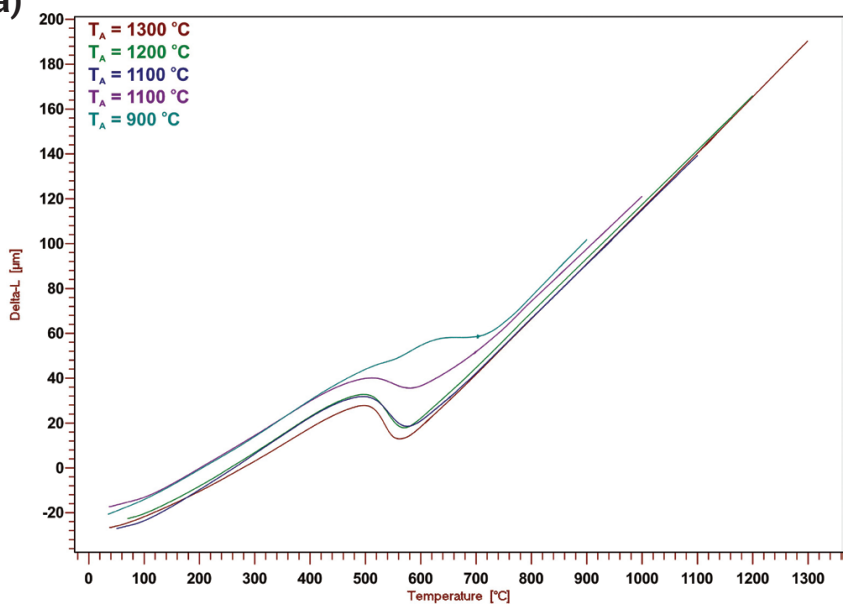

b)

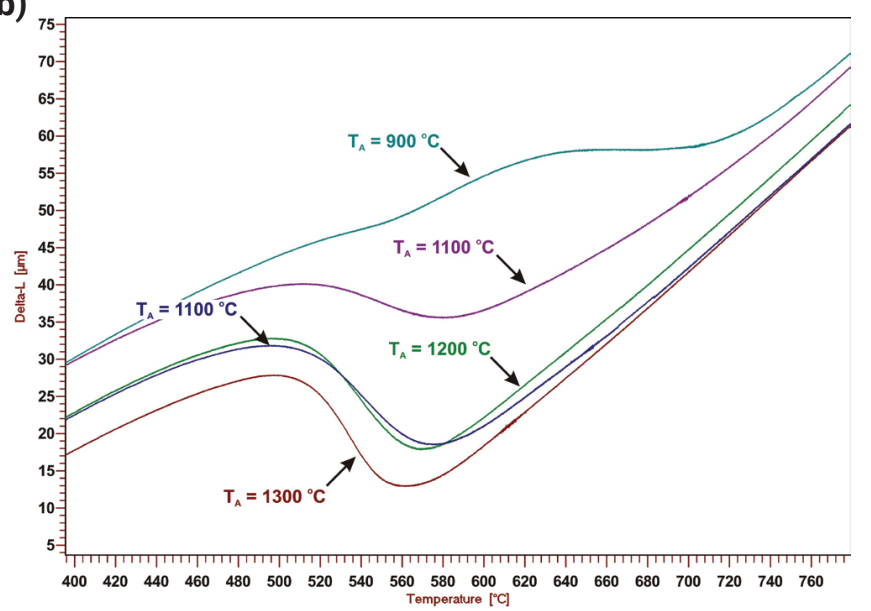

Rys. 2. Zestawienie dylatogramów chłodzenia próbek z szybkością $1^{\circ} \mathrm{C} / \mathrm{s}$ od wybranych temperatur austenityzowania: a) cały przebieg chłodzenia, b) powiększony wybrany fragment

Fig. 2. Comparison of dilatograms for sample cooling at a rate of $1^{\circ} \mathrm{C} / \mathrm{s}$ from selected austenitizing temperatures: a) the entire cooling process, b) enlarged selected fragment

a)

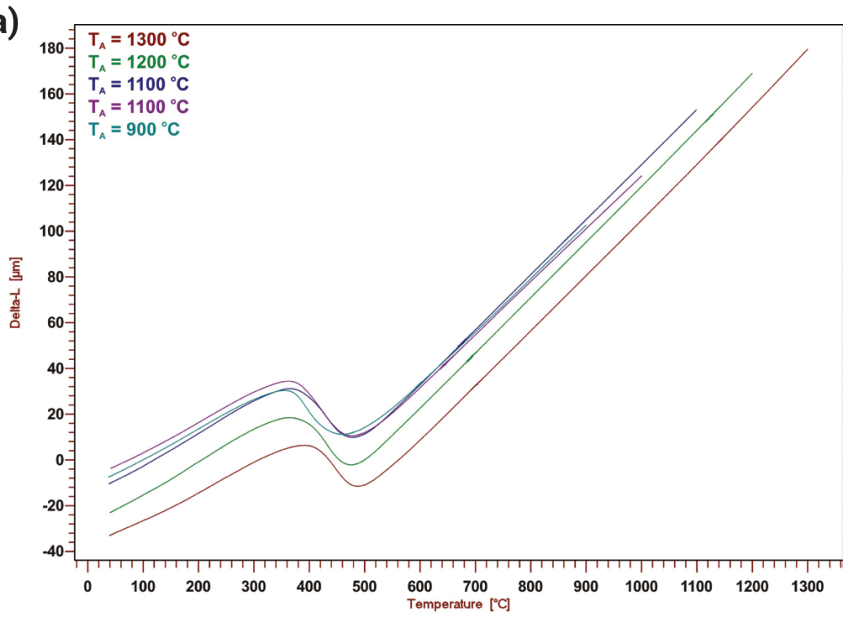

b)

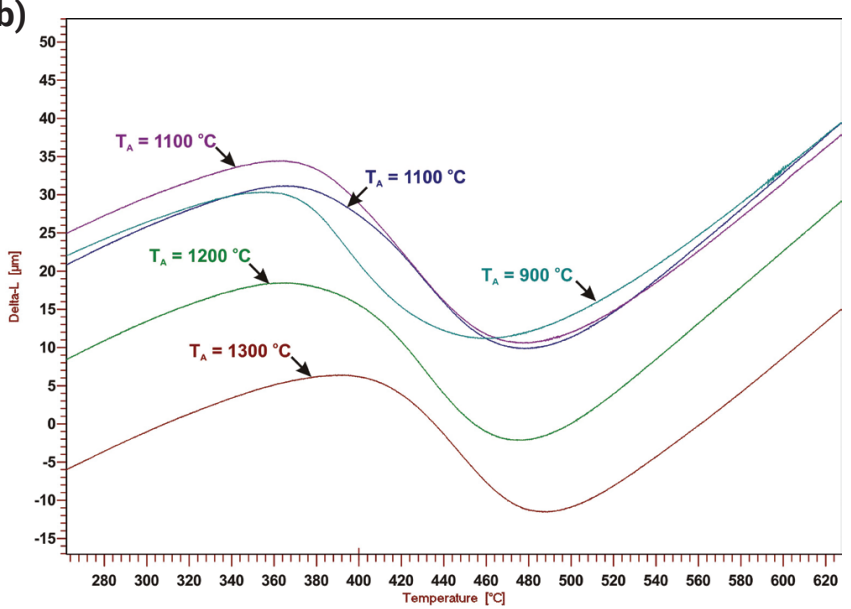

Rys. 3. Zestawienie dylatogramów chłodzenia próbek z szybkością $5^{\circ} \mathrm{C} / \mathrm{s}$ od wybranych temperatur austenityzowania: a) cały przebieg chłodzenia, b) powiększony wybrany fragment

Fig. 3. Comparison of dilatograms for sample cooling at a rate of $5{ }^{\circ} \mathrm{C} / \mathrm{s}$ from selected austenitizing temperatures: a) the entire cooling process, b) enlarged selected fragment

Dalszy wzrost temperatury do $1300{ }^{\circ} \mathrm{C}$ powoduje kolejne zwiększenie obszarów bainitycznych. Analizując mapy twardości dla szybkości chłodzenia $1{ }^{\circ} \mathrm{C} / \mathrm{s}$ można zauważyć, że najbardziej jednorodny rozkład twardości uzyskano w przypadku próbek chłodzonych z szybkością $1^{\circ} \mathrm{C} / \mathrm{s}$ od temperatury austenityzowania $1100{ }^{\circ} \mathrm{C}, 1200{ }^{\circ} \mathrm{C}$ oraz $1300{ }^{\circ} \mathrm{C}$. W obszarach tych w mikrostrukturze przeważa bainit z niewielkim udziałem ferrytu na granicach ziaren. Natomiast największą niejednorodność uzyskano dla próbki chłodzonej od temperatury $900{ }^{\circ} \mathrm{C}$. W tym przypadku widać wyraźnie duży gradient twardości. Tak duża niejednorodność rozkładu twardości wynika z faktu, że mikrostruktura stali w tym wypadku składała się z bainitu, ferrytu oraz perlitu. Zastosowanie wyższej temperatury austenityzowania tj. $1100^{\circ} \mathrm{C}$ powoduje zanik obszarów o twardości zawartej w przedziale 150 do 185 HV. Jak widać, wzrost temperatury austenityzowania spowodował ujednorodnienie profilu twardości.

W mikrostrukturach próbek chłodzonych z szybkością $5{ }^{\circ} \mathrm{C} / \mathrm{s}$ obserwuje się w każdym przypadku bainit i martenzyt. Wraz ze wzrostem temperatury austenityzowania w mikrostrukturze stopów stopniowo zmniejsza się udział objętościowy bainitu na rzecz martenzytu. Widoczny jest również rozrost ziarna wraz ze wzrostem temperatury austenityzowania. Przedstawione mapy rozkładu twardości dla szybkości chłodzenia $5{ }^{\circ} \mathrm{C} / \mathrm{s}$ wskazują na ujednorodnienie twardości, które następuje dopiero po podwyższeniu temperatury austenityzowania do $1300{ }^{\circ} \mathrm{C}$. Powoduje to zanik obszarów o twardości zawartej w przedziale $450 \div 500 \mathrm{HV}$, a przeważają twardości w przedziale od 350 $\div 400 \mathrm{HV}$. Wraz ze wzrostem temperatury austenityzowania zwiększa się jednorodność uzyskiwanych rozkładów twardości. 
a)

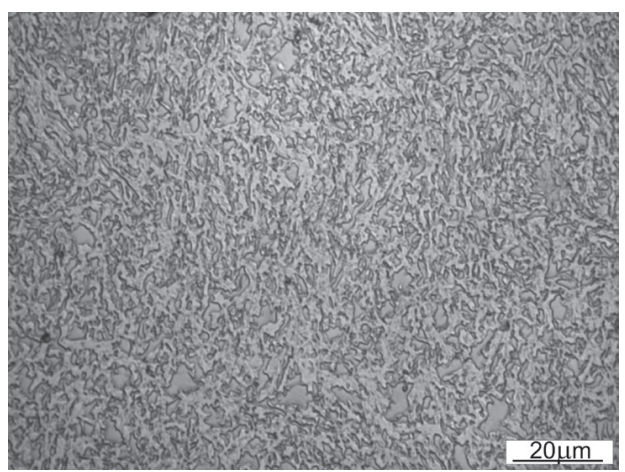

b)

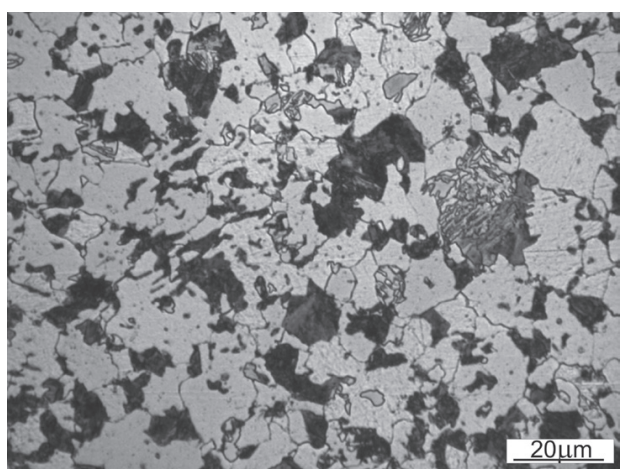

c)

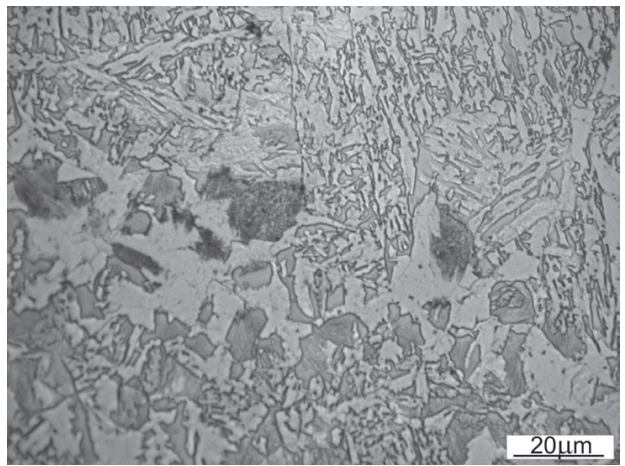

d)

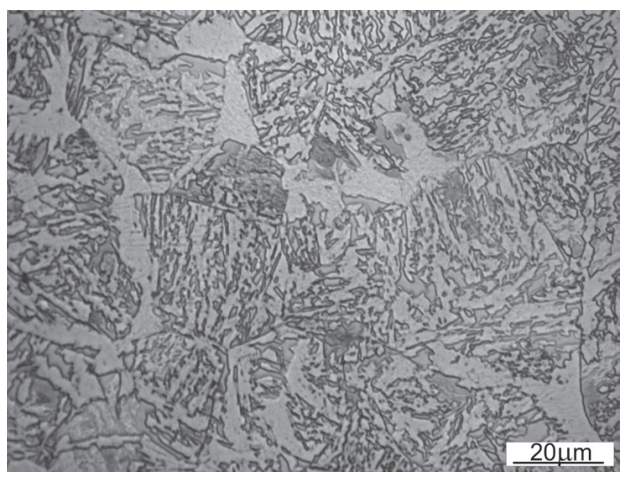

e)

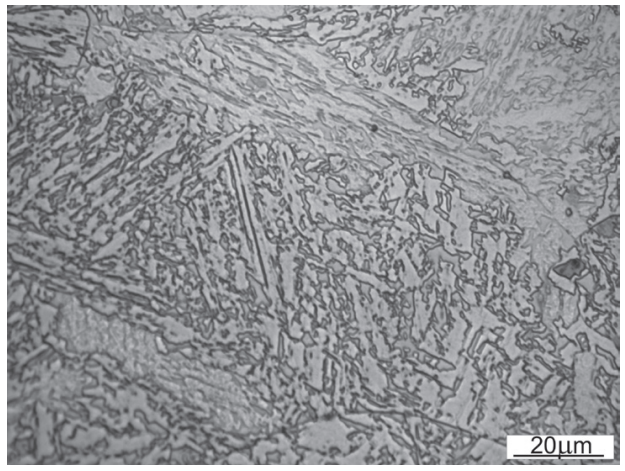

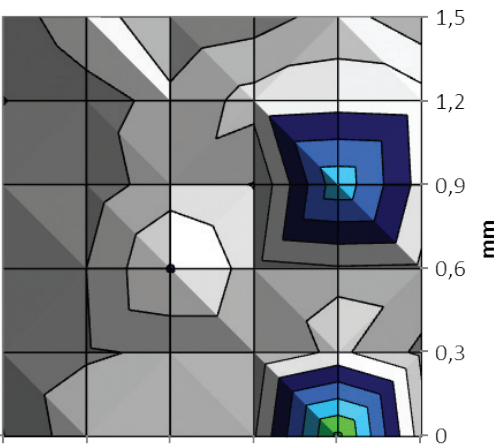

$\begin{array}{llllll}0,3 & 0,6 & 0,9 & 1,2 & 1,5 & \mathrm{~mm}\end{array}$
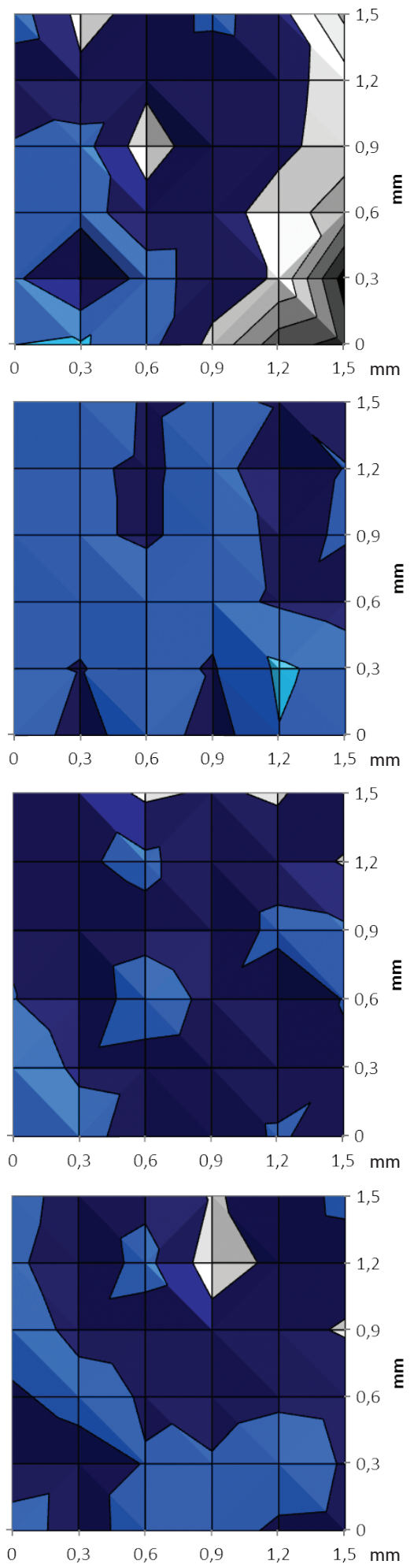

$\square 475-500 \quad \square 450-475$

口425-450 口400-425

ㅁ375-400 ㄴ 350-375

ㅁ325-350 중-325

口275-300 घ250-275

225-250 200-225

$\square$ 175-200 ロ150-175

-125-150

ロ475-500 ロ 450-475

口425-450 口400-425

ㅁ375-400 ロ $350-375$

ロ 325-350 300-325

口275-300 घ250-275

225-250 200-225

$\square 175-200 \quad \square 150-175$

-125-150

$$
\begin{aligned}
& \square 475-500 \quad \square 450-475 \\
& \square 425-450 \quad \square 400-425 \\
& \square 375-400 \quad \square 350-375 \\
& \square 325-350 \quad \square 300-325 \\
& \square 275-300 \quad \square 250-275 \\
& \square 225-250 \quad \square 200-225 \\
& \square 175-200 \quad \square 150-175 \\
& \square 125-150
\end{aligned}
$$

ロ475-500 ロ 450-475

口425-450 प400-425

ロ 375-400 ロ 350-375

ロ 325-350 ロ $300-325$

ロ275-300 \250-275

225-250 200-225

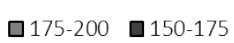

-125-150

ロ 475-500 ロ 450-475

ロ 425-450 ㄴ 400-425

ロ 375-400 ロ 350-375

ㅁ325-350 ㅁ300-325

ㅁ275-300 घ250-275

225-250 ㄴ200-225

ロ175-200 ロ 150-175

-125-150

Rys. 4. Mikrostruktura próbek dylatometrycznych chłodzonych z szybkością $1{ }^{\circ} \mathrm{C} / \mathrm{s}$ uprzednio nagrzanych do temperatury: a) $900{ }^{\circ} \mathrm{C}$, b) $1000{ }^{\circ} \mathrm{C}$, c) $1100^{\circ} \mathrm{C}$, d) $1200^{\circ} \mathrm{C}$, e) $1300^{\circ} \mathrm{C}$ wraz z odpowiadającymi im mapami twardości

Fig. 4. Microstructure of dilatometric samples cooled at $1{ }^{\circ} \mathrm{C} / \mathrm{s}$ pre-heated to: a) $900{ }^{\circ} \mathrm{C}$, b) $\left.\left.1000{ }^{\circ} \mathrm{C}, \mathrm{c}\right) 1100^{\circ} \mathrm{C}, \mathrm{d}\right) 1200^{\circ} \mathrm{C}$, e) $1300{ }^{\circ} \mathrm{C}$ with the corresponding hardness maps 
a)

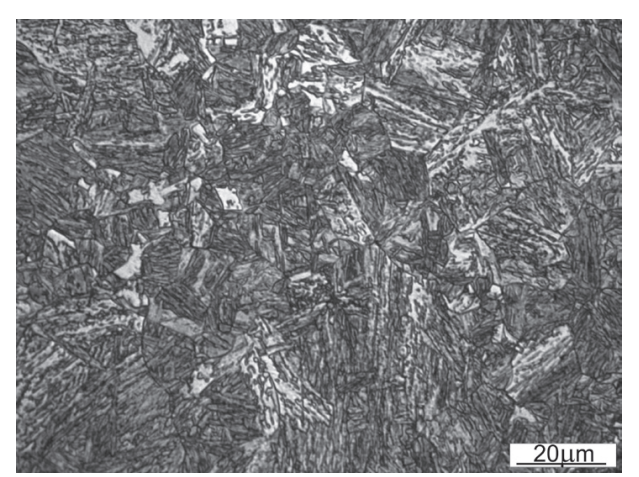

b)

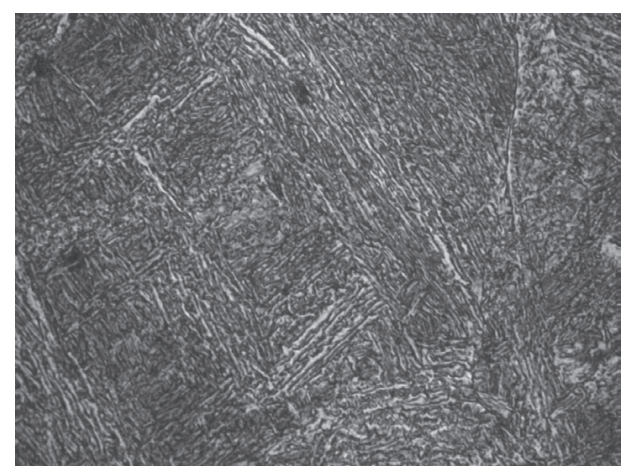

c)

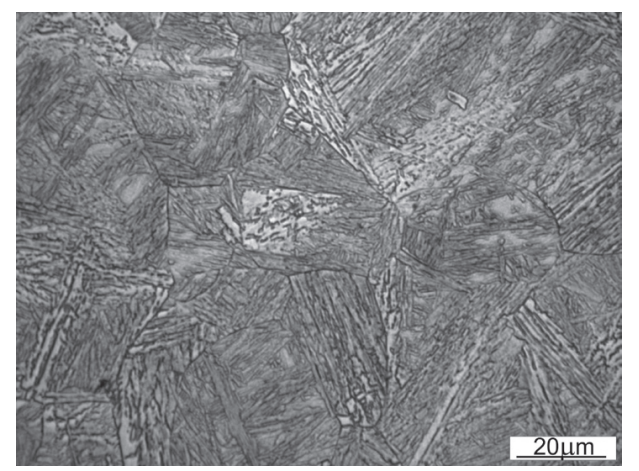

d)

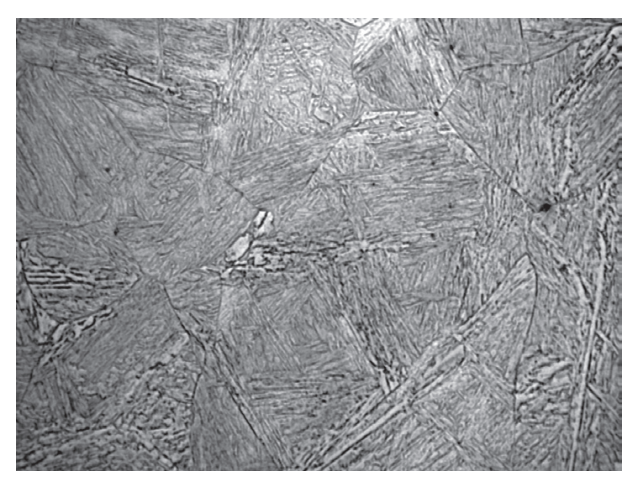

e)

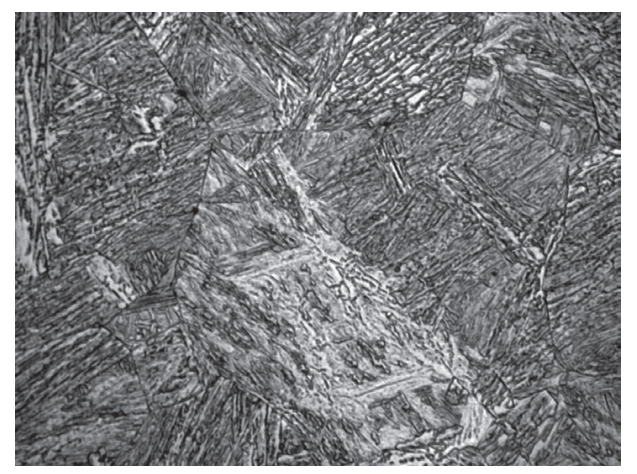

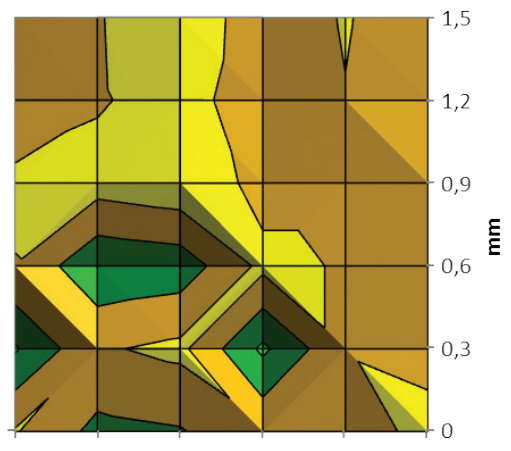

$0,3 \quad 0,6 \quad 0,9 \quad 1,2 \quad 1,5 \quad \mathrm{~mm}$

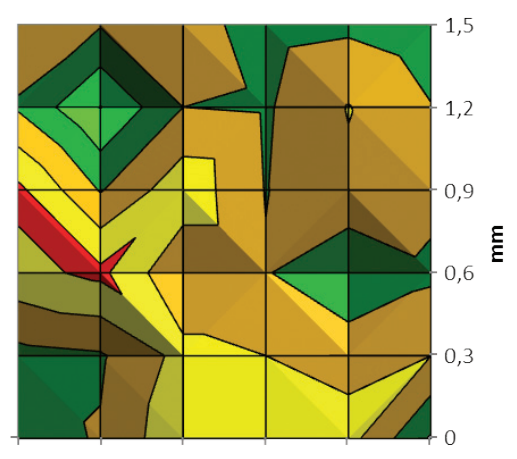

ロ 475-500 प 450-475

ロ 425-450 口400-425

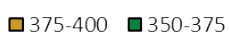

ㅁ325-350 ㅁ300-325

口275-300 -250-275

口225-250 ㄴ200-225

$\square 175-200 \quad \square 150-175$

- $125-150$
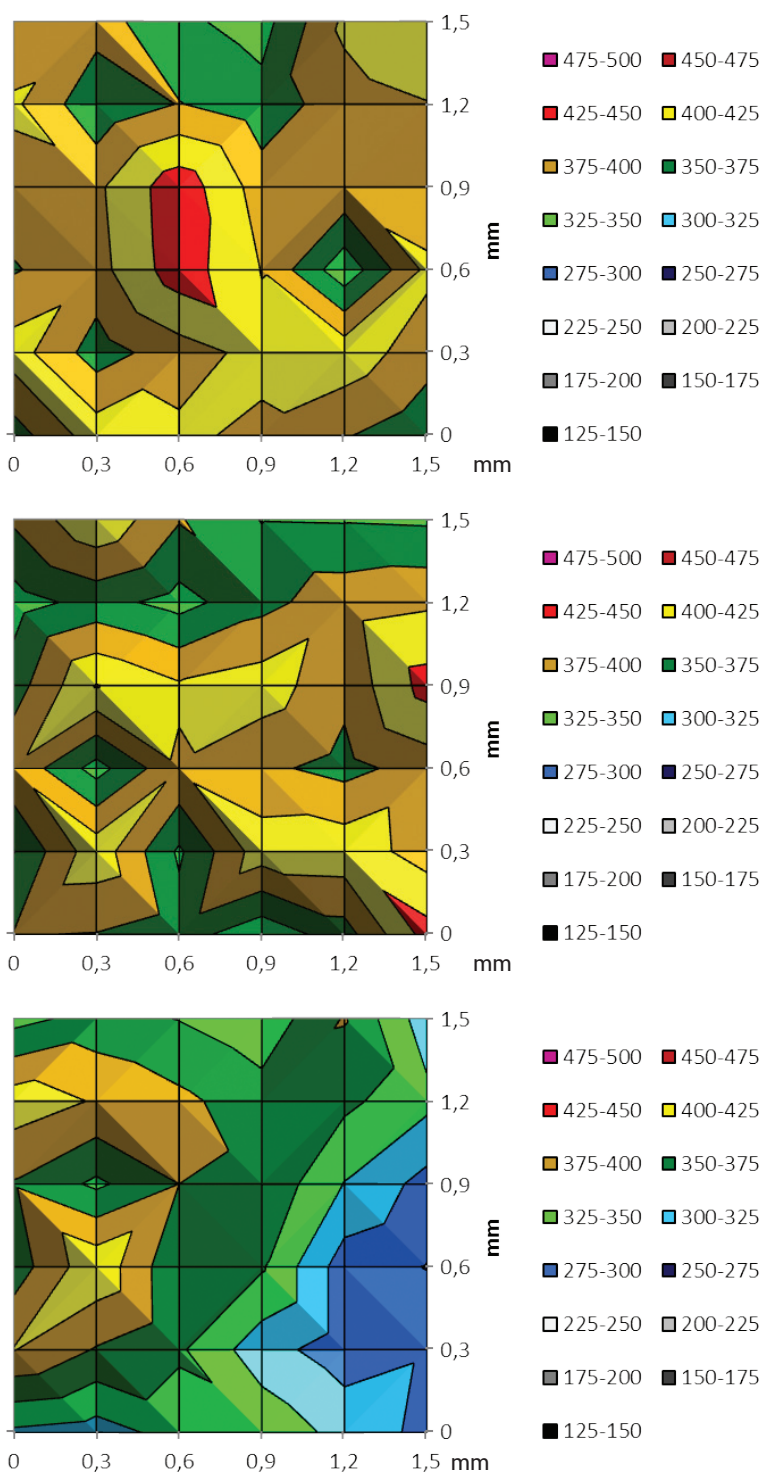

Rys. 5. Mikrostruktura próbek dylatometrycznych chłodzonych z szybkością $5{ }^{\circ} \mathrm{C} / \mathrm{s}$ uprzednio nagrzanych do temperatury: a) $900{ }^{\circ} \mathrm{C}$, b) $1000^{\circ} \mathrm{C}$, c) $1100^{\circ} \mathrm{C}$, d) $1200^{\circ} \mathrm{C}$, e) $1300^{\circ} \mathrm{C}$ wraz z odpowiadającymi im mapami twardości

Fig. 5. Microstructure of dilatometric samples cooled at $5^{\circ} \mathrm{C} / \mathrm{s}$ pre-heated to: a) $900{ }^{\circ} \mathrm{C}$, b) $1000{ }^{\circ} \mathrm{C}$, c) $1100{ }^{\circ} \mathrm{C}$, d) $1200{ }^{\circ} \mathrm{C}$, e) $1300{ }^{\circ} \mathrm{C}$ with the corresponding hardness maps 


\section{Podsumowanie}

Wykonane w pracy badania i analiza uzyskanych wyników pozwalają na sformułowanie następujących wniosków:

1) Dla próbki chłodzonej z szybkością $1{ }^{\circ} \mathrm{C} / \mathrm{s}$ podwyższenie temperatury austenityzowania wpłynęło na zmniejszenie efektu dylatacyjnego pochodzącego od przemian dyfuzyjnych w szczególności perlitzyacji. Przy temperaturze $1100{ }^{\circ} \mathrm{C}$ obserwuje się zanik efektu od przemiany perlitycznej, a dominują jedynie efekty dylatacyjne związane z powstawaniem ferrytu i bainitu. Świadczy to o wzroście hartowności z temperaturą austenityzowania.

2) W mikrostrukturze próbki dylatometrycznej po chłodzeniu z szybkością $1^{\circ} \mathrm{C} / \mathrm{s}$ od temperatury $900{ }^{\circ} \mathrm{C}$ uzyskano ferryt, perlit i niewielkie ilości bainitu. Po zwiększeniu temperatury austenityzowania do $1000^{\circ} \mathrm{C}$ następuje znaczny wzrost udziału objętościowego bainitu, przy czym w mikrostrukturze nadal zauważalne są obszary ferrytyczno-perlityczne.

3) Analizując mapy twardości dla szybkości chłodzenia $1{ }^{\circ} \mathrm{C} / \mathrm{s}$ można zauważyć, że najbardziej jednorodny rozkład twardości uzyskano w przypadku próbek chłodzonych z szybkością $1{ }^{\circ} \mathrm{C} / \mathrm{s}$ od temperatury austenityzowania 1100,1200 oraz $1300{ }^{\circ} \mathrm{C}$.

4) W mikrostrukturach próbek chłodzonych z szybkości $5{ }^{\circ} \mathrm{C} / \mathrm{s}$ obserwuje się w każdym przypadku bainit i martenzyt.

5) Przedstawione mapy rozkładu twardości dla szybkości chłodzenia $5{ }^{\circ} \mathrm{C} / \mathrm{s}$ wskazują na ujednorodnienie twardości, co następuje dopiero po podwyższeniu temperatury austenityzowania do $1300{ }^{\circ} \mathrm{C}$.

\section{Literatura}

[1] Hardox - Das Verschleißblech der vielen Möglichkeiten, Wydawnictwo SSAB, Oxelösund, 2002.

[2] Dudziński W., Konat Ł., Pękalska L., Pękalski G.: Struktury i właściwości stali Hardox 450 i Hardox 500, Inżynieria Mater. 3, 2006, s. 139-142.

[3] Pękalski G., Konat Ł.: Rozpoznanie i analiza efektów zastosowań stali Hardox, Rap. Inst. Mater. I Mech. Tech. Serii SPR 4/2005.

[4] Pawlak K.: A review of high-strength wear resistant steel - hardox, 2015.

[5] Konat Ł., Pękalski G.: Rozpoznanie i analiza efektów zastosowań stali Hardox, Raport PWr serii SPR, 2005.

[6] Malkiewicz T.: Metaloznawstwo stopów żelaza, 2nd ed., PWN, Warszawa - Kraków, 1978

[7] Blicharski M.: Inżynieria materiałowa. Stal, Wydawnictwa NaukowoTechniczne, Warszawa 2004, n.d.
[8] Sotskov N.I., Goritskii V.M., Morozova L.M.: Effect of Tempering Temperature on The Resistance of High- Strength Steel 40Kh Bolts To Corrosion Cracking, Metalloved. I Termicheskaya Obrab. Met. 292, 1992, pp. 4-7.

[9] Mulholland M.D., Seidman D.N.: Nanoscale co-precipitation and mechanical properties of a high-strength low-carbon steel, Acta Mater. 59, 2011, pp. 1881-1897.

[10] Mikuła J.: Spawalność Stali, Zeszty Naukowe Politechniki Krakowskiej, 2001.

[11] Kostin V.: Microstructure of Haz Metal of Joints of High-Strength Structural Steel Weldox 1300, 2015.

[12] PracaZbiorowa, Poradnik inżyniera - spawalnictwo, Wydawnictwo Naukowo-Techniczne, Warszawa, 1983.

[13] Tasak E.: Spawalność stali, FOTOBIT, Kraków, 2002. 